\title{
Oral Health-Related Quality of Life Among People Living with HIVIAIDS
}

\author{
Norkhafizah Saddki and Wan Majdiah Wan Mohamad \\ School of Dental Sciences, Universiti Sains Malaysia, \\ Health Campus, Kubang Kerian, Kelantan, \\ Malaysia
}

\section{Introduction}

Since it was first recognized in early 1980s, the Acquired Immunodeficiency Syndrome (AIDS) has been one of the most destructive diseases recorded in the world history. The devastating impact of HIV/AIDS on individual patient, family, community and the nation is vast. The disease not only robs a country of its monetary resources in covering for the costs of HIV prevention and treatment, but also of the nation's human resources when young productive lives are affected. The latest statistics suggested that the overall growth of the disease has stabilised with declining number of new HIV cases since the last decade. However, the number of people living with HIV/AIDS (PLWHA) remained high and appeared to be still on the rise (UNAIDS, 2010).

With increasing availability and use of highly active antiretroviral therapy (HAART) in 1996, fewer deaths due to AIDS-related diseases have been observed. Worldwide, about 1.8 million HIV-related deaths were reported in 2009 as compared to the peak 2.1 million in 2004. In Southern Alberta, Canada, analysis of AIDS death records between pre-HAART (1984-1996) and HAART (1997-2003) periods revealed reduction in crude mortality rate from 117 deaths per 1000 patient-years pre-HAART to 24 in the HAART period (Krentz et al., 2005). Across Europe, the HIV-related death rates reduced substantially between September, 1995, and March, 1998, in a large cohort of 4270 HIV-infected patients to less than a fifth of their previous level (Mocroft et al., 1998). A study in Taiwan compared the mortality rate of 10,162 HIV-infected patients whose diagnosis was made in three different periods: the preHAART period, from 1 January 1984 to 31 March 1997; the early HAART period, from 1 April 1997 to 31 December 2001; and the late HAART period, from 1 January 2002 to 31 December 2005 (Yang et al., 2008). Results showed that the mortality rate of HIV-infected patients declined significantly from 10.2 deaths per 100 person-years in the pre-HAART period to 6.5 deaths and 3.7 deaths per 100 person-years in the early and late HAART periods, respectively. This increase in survival rates contributes to the increasing number of PLWHA as AIDS is no longer a lethal disease but has been transformed into a chronic condition.

Oral lesions are common in PLWHA. Some oral manifestations have been documented as early markers of HIV infection and as predictors of disease progression. Among the most common oral manifestations of HIV include oral candidiasis, oral hairy leukoplakia and necrotizing ulcerative periodontitis (Coogan et al., 2005; Ranganathan \& Hemalatha, 2006). 
Oral problems may give rise to physical, functional and emotional discomfort, dysfunction, or disability which in turn has been shown to affect the overall quality of life (QOL) of PLWHA (Coulter et al., 2002; Yengopal \& Naidoo, 2008). As people are living longer with $\mathrm{HIV}$, the study on QOL has emerged as an important factor in management of HIV infection (Grossman et al., 2003). This chapter aims to describe the epidemiology and manifestations of oral lesions commonly associated with HIV/AIDS and the impact of oral health problems on the QOL of PLWHA.

\section{Epidemiology of HIV-associated oral manifestations}

Oral lesions are common in individuals with HIV infection. Many epidemiologic studies have been conducted around the world to study the prevalence of oral lesions among PLWHA not long after the virus was first discovered and reported in the United States in 1981. Bhayat et al. (2010) reported that oral manifestations of HIV/AIDS occurred in more than $60 \%$ of HIV-positive patients and were often the first sign of underlying immunosuppression. Another study by Nittayananta et al. (2002) found that more than $90 \%$ of HIV-infected individuals will have at least one oral manifestation during the illness. Not only HIV-related oral lesions are among the early clinical features of the infection, but can also indicate the stage and progress of the disease. Prevalence of oral lesions has been shown to be significantly higher in individuals with a CD4+ count less than 200 cells $/ \mathrm{mm}^{3}$ and a viral load greater than 3000 copies/mL (Bravo et al., 2006; Greenspan et al., 2000; Tappuni \& Fleming, 2001). The importance of oral lesions as clinical indicators of HIV infections and markers of clinical progression to AIDS has been demonstrated in many studies that reported their association with CD4+ depletion and high viral load (Bravo et al., 2006; Campo et al., 2002; Chattopadhyay et al., 2005; Glick et al., 1994; Greenspan et al., 2000; Patton, 2000; Ramírez-Amador et al., 2003; Shiboski et al., 2001).

A comprehensive review of epidemiologic studies on HIV-related oral lesions reported from developed and developing countries over more than a decade, encompassing the preHAART and early-HAART period from 1986 to 2000, revealed oral candidiasis as the most common lesion found in all ages across the world (Patton et al., 2002). Prevalence of the lesion, however, ranged considerably from as low as 5\% found in two separate studies in Minnesota (Little et al., 1994; Melnick et al., 1991) to as high as 94\% among those with AIDSdefining illnesses in Zaire (Tukutuku et al., 1990). This review paper by Patton et al. (2002), which was the outcome of an International Workshop that addressed the prevalence and classification of HIV/AIDS associated oral lesions, identified hairy leukoplakia as the second most reported oral lesion with prevalence that ranged from $2 \%$ in Nairobi, Kenya (Wanzala et al., 1989) to $43 \%$ in Mexico (Gillespie \& Mariño, 1993). This wide-ranged prevalence was due to variations in the populations studied, including differences in the prevalence of AIDS diagnoses, CD4+ count, or diagnostic techniques used.

Prevalence of other oral lesions commonly associated with HIV also varies according to region of the world and the population examined (Patton et al., 2002). According to the review by Patton et al. (2002), Kaposi's sarcoma was reported to be present in $12 \%$ of 83 heterosexual AIDS patients in Kinshasa, Zaire (Tukutuku et al., 1990), while higher frequency of $38 \%$ was found among 84 AIDS patients in the United States (Roberts et al., 1988). HIV-related periodontal lesions, namely linear gingival erythema, necrotizing ulcerative gingivitis and necrotizing ulcerative periodontitis were found in up to $22 \%$ of patients in New York (Lamster et al., 1994), 24\% in Argentina (Gillespie \& Mariño, 1993), 
and $23 \%$ in India (Anil \& Challacombe, 1997), respectively. Of these periodontal lesions, necrotizing ulcerative periodontitis is the most severe form. Lower prevalence was reported for non-Hodgkin's lymphoma which was detected in 5\% of 124 AIDS patients in Thailand (Nittayananta \& Chungpanich, 1997) and 2\% in San Francisco (Silverman Jr et al., 1986).

The introduction of HAART has not only resulted in significant decline in mortality associated with HIV across the world, significant reduction was also seen in the prevalence of most AIDS-defining illnesses and opportunistic infections (Buchacz et al., 2010; Kaplan et al., 2000; Mocroft et al., 2004). Similarly, there has been a downward trend in the prevalence of oral opportunistic lesions in response to the use of HAART (Franceschi et al., 2008; Patton et al., 2000; Ramírez-Amador et al., 2003; Shiboski, 2002; Yang et al., 2010). Notable reduction was reported in the prevalence of two most common HIV-associated lesions, oral candidiasis and hairy leukoplakia (Eyeson et al., 2002; Nicolatou-Galitis et al., 2004; Patton et al., 2000; Ramírez-Amador et al., 2003). Despite the great success of HAART, the therapy remains an expensive option that may be unaffordable to many, especially those living in low-income countries (WHO et al., 2009). It was reported that at least 5 million PLWHA in need of treatment are not able to have access to the life-prolonging therapy although the availability of HAART has increased rapidly from $7 \%$ in 2003 to $42 \%$ in 2008 to reach over four million people in low- and middle-income countries.

Nevertheless, even when HAART is available to reduce the viral load, many other factors have been suggested to predispose to oral lesions in HIV-infected individuals such as cigarette smoking, heroin/methadone use, poor oral hygiene, and socio-demographic factors such as older age, lower education level and lower household income (Chattopadhyay et al., 2005; Ferreira et al., 2007; Greenspan et al., 2000; Nittayananta et al., 2001; Noce et al., 2009; Shiboski et al., 1999a). In addition, studies have suggested that HIV disease progression can be influenced by psychological factors (Leserman, 2003; Leserman, 2008). Specifically, feelings of hopelessness, depressed mood, and avoidant coping have been shown to be associated with reduced CD4+ cell count and increased viral load in a study among 177 HIV-positive patients (Ironson et al., 2005). Owing to the established association of CD4+ count and viral load with prevalence of oral lesions, it is possible that psychosocial factors may also have an effect on the incidence of oral lesions in HIV patients. Besides, related psychological and social impact including stigma of HIV infection should also be considered in general management of PLWHA as these may further influence health-seeking behaviour, diagnosis, quality of care provided, treatment and its outcomes, and adherence to therapy (Carr \& Gramling, 2004; WHO, 2008). There have been several reports that suggested while the oral health needs among HIV-infected patients are high, utilization of care unfortunately has been poor (Dobalian et al., 2003; Mascarenhas \& Smith, 1999; Patton et al., 2003; Shiboski et al., 1999b). These circumstances can develop a vicious cycle as poor use of services will undoubtedly create greater unmet needs which in turn further deteriorate oral conditions and increase the oral health impact among PLWHA. On the whole, although the prevalence of oral health conditions among PLWHA has mainly reduced, the problem remains as a fundamental component of disease progression. It is important that clinicians are able to diagnose oral lesions related to the infection, recognise the predisposing and risk factors, and initiate appropriate therapy.

\section{Oral manifestations strongly associated with HIV}

In 1993, the EC-Clearinghouse on Oral Problems Related to HIV Infection and the World Health Organization (WHO) Collaborating Centre on Oral Manifestations of the 
Immunodeficiency Virus (EC-Clearinghouse \& WHO, 1993) published a consensus on the classification of oral manifestations related with HIV infection and their diagnostic criteria. The lesions were grouped into three categories depending on their strength of association with the infection. Oral candidiasis, hairy leukoplakia, specific forms of periodontal disease (linear gingival erythema, necrotizing ulcerative gingivitis and necrotizing ulcerative periodontitis), Kaposi's sarcoma and non-Hodgkin's lymphoma have been classified as oral lesions strongly associated with HIV infection.

\subsection{Oral candidiasis}

Oral candidiasis is predominantly caused by Candida albicans (Laskaris, 2000). It is an early manifestation of HIV that can occur in patients who appear otherwise healthy. In HIVinfected patients, candidal infection can occur in two major forms, pseudomembranous and erythematous. The pseudomembranous type presents as white or yellowish spots or plaque that can be wiped off, revealing an erythematous surface. The soft palate, buccal mucosa, lateral borders of the tongue, commisures, lips and gingival are more frequently affected (Laskaris, 2000). On the other hand, the erythematous form presents as red area usually on the palate and the dorsum of the tongue although occasionally it can be located on the buccal mucosa (EC-Clearinghouse \& WHO, 1993; Laskaris, 2000). White spots and plaque may be seen, but these are not usually conspicuous (Laskaris, 2000).

Clinical diagnosis of oral candidiasis is confirmed with the presence of candidal hypae in oral smears of the affected oral mucosa (Ramírez-Amador et al., 2006). The treatment of oral candidiasis includes azole (ketoconazole, fluconazole, itraconazole) and polyene drugs (nystatin and amphotericine B). However, resistance to these drugs and recurrences are frequent (Laskaris, 2000).

\subsection{Oral hairy leukoplakia}

Oral hairy leukoplakia is commonly found in patients at the late stage of HIV infection (Greenspan \& Greenspan, 1992). It usually appears when CD4+ T cell count drops below 150 cells/mm3 (Glick et al., 1994). Although the actual cause and pathogenesis of the lesion is unclear, Epstein-Barr virus seems to play an important role (Cruchley et al., 1997; Tüzün et al., 2005). It is usually diagnosed clinically as asymptomatic, non-removable, flat or vertically correlated bilateral whitish or gray lesions on the lateral margins of the tongue (EC-Clearinghouse \& WHO, 1993; Laskaris, 2000). Sometimes it occurs on the dorsum of the tongue and occasionally on the buccal mucosa. Appearance of the lesion may vary from subtle translucent white to dense white plaque, and Epstein-Barr virus has been detected by in situ hybridization of the lesion (Webster-Cyriaque et al., 1997). Oral hairy leukoplakia is almost always asymptomatic, self-limiting and often requires no treatment. Antifungal therapy may resolve the symptoms of superimposed candidosis but the lesion will not resolve completely. High dose acyclovir, zidovudine and podophyllin are the drugs of choice while surgical excision can be offered to patients who request for removal of the lesion (Scully \& McCarthy, 1992). Oral hairy leukoplakia tends to recur when treatment is discontinued (Laskaris, 2000).

\subsection{Linear gingival eythema}

Linear gingival erythema appears as distinct fiery red band about 2-3 mm width along the free gingival margin (EC-Clearinghouse \& WHO, 1993). Initially, the lesion was thought to be directly associated with HIV, and was thus previously called HIV-associated gingivitis. 
However, subsequent evidence showed that the lesion is not specific to HIV infection. It also occurs in HIV negative immunocompromised patients and was renamed as linear gingival erythema. Clinical oral examination will reveal inflamed gingival tissues which bleed easily upon manipulation. There is absence of ulceration, periodontal pocket, or attachment loss.

Unlike conventional periodontal disease, linear gingival erythema is not associated with the amount of plaque. It does not respond well to oral hygiene measures, removal of dental plaque and calculus. However, plaque and calculus should be removed in these patients to help reduce the erythema and possibly accelerate the healing. This procedure should be done very carefully to avoid excessive bleeding. Therapeutic protocol for linear gingival erythema includes $0.12 \%$ chlorexidine gluconate mouth rinse twice daily and systemic antibiotics such as metronidazole (Flagyl) if the lesion persists despite the preceding therapy.

\subsection{Necrotizing ulcerative gingivitis}

Clinically, necrotizing ulcerative gingivitis may present with fiery red and swollen gingiva as well as destruction of one or more interdental papillae. The onset of the disease is either acute or subacute. In acute stage, ulceration, necrosis and sloughing of both gingival margin and the top of interdental papillae are common findings. The anterior gingiva is most frequently affected. Pain, bleeding and halitosis are the common symptoms. Subacute stage is characterized by localized or generalized acute, painful ulceronecrotic lesions of the oral mucosa beyond the gingiva. In acute phase, treatment includes metronidazole, $500 \mathrm{mg}$ three times daily for 6 to 8 days and topical mouthwashes. Conventional periodontal treatment (plaque control measures, root planing, scaling) should follow (Laskaris, 2000).

\subsection{Necrotizing ulcerative periodontitis}

HIV-associated periodontitis is a serious and rapidly progressive condition, usually occur in severe immunosuppression when CD4+ T cell count is less than 100 cells $/ \mathrm{mm}^{3}$ (Glick et al., 1994). Clinically, necrotizing ulcerative periodontitis is characterized by gingival ulceration and necrosis as well as rapid and progressive destruction of the periodontal attachment and loosening of teeth (EC-Clearinghouse \& WHO, 1993; Patton, 2003). Spontaneous bleeding, deep-seated pain, halitosis, erythema and edema are the prominent features (Laskaris, 2000). This condition can be treated with systemic administration of metronidazole or tetracycline for 8 to 12 days in conjunction with topical antibacterial mouthwashes. Conventional periodontal treatment maintenance and prevention should follow (Robinson, 1997). However, relapses are common.

\subsection{Kaposi's sarcoma}

Kaposi's sarcoma is the most common malignancies in HIV-infected patients (Wood \& Harrington Jr, 2005). Human Herpes Virus-8 has been found to be necessary but not sufficient for its development because other factors such as immunosuppression are also required (Boshoff et al., 1995; Laskaris, 2000; Whitby et al., 1995; Wood \& Harrington Jr, 2005). Clinically, in the early phase, patients with oral Kaposi's sarcoma may present with a blue, red or purple macules on the palate, gingival and/or tongue (Casiglia \& Woo, 2000; Glick et al., 1994). The lesion may progress to become raised and nodular, and subsequently may result in ulceration, bleeding and pain (Casiglia \& Woo, 2000; Laskaris, 1996). Biopsy of the lesion is required to confirm the diagnosis (Laskaris, 2000). Histopathologically, it is characterized by proliferation of spindle-shaped cells that form the vascular channels (Casiglia \& Woo, 2000; Wang et al., 2007). The differential diagnoses of oral Kaposi's 
sarcoma include bacillary angiomatosis, pyogenic granuloma, peripheral giant cell granuloma, leiomyoma, angiosarcoma, nevi, malignant melanoma and oral lesions of amyloidosis (Laskaris, 2000).

Treatment for Kaposi's sarcoma mainly focus on palliation and local control since chemotherapy may further suppress the immune system and favor the proliferation of the lesion (Gascón \& Schwartz, 2000). Local measures include excision, laser ablation, radiation or intralesional injection. A small lesion may be completely excised or ablated. Radiotherapy reduces the pain and results in regression of the lesion. However, it may give rise to potential side effects such as taste loss, mucositis as well as superimposed candidal infection. Prophylactic antifungal therapy with amphotericin B rinses and ketoconazole is beneficial to minimize this complication (Piedbois et al., 1994). Systemic involvement of Kaposi's sarcoma is usually treated with chemotherapy. Regimens include the use of vinblastine as a single agent or combination of adriamycin, bleomycin and vincristine (Casiglia \& Woo, 2000).

\subsection{Non-Hodgkin's lymphoma}

Non-Hodgkin's lymphoma is the second most common intraoral neoplasm in patients with HIV infection, particularly those with CD4+ count less than 100 cells $/ \mathrm{mm}^{3}$ (Laskaris, 2000). As compared with healthy individuals, HIV patients have 60 to 70 times greater risk of developing the malignancy (Reynolds et al., 1993). Epstein Barr virus is a known risk factor for HIV-related non-Hodgkin's lymphoma (Wood \& Harrington Jr, 2005). Factors such as viral infection can precipitate either chronic antigenic stimulation or immunosuppression which may provide a preferential environment for the development of non-Hodgkin's lymphoma (Fisher \& Fisher, 2004).

Clinically, patients may present with intraoral ulcerations or soft tissue masses which are painful and rapidly enlarged. The most common sites include palate, retromolar pad, tonsillar pillars and tongue (Green \& Eversole, 1989). However, most HIV patients presented with oral non-Hodgkin's lymphoma may already have nodal and extranodal involvement at the time of diagnosis (Carbone et al., 1995). Patients with localized disease are treated with radiotherapy. Chemotherapy is another treatment option. However, chemotherapy can induce profound neutropenia which can be treated effectively with concomitant administration of granulocyte-macrophage colony-stimulating factor (Kaplan et al., 1991). Complete remission occurs in approximately $65 \%$ of patients with the median survival time between 4 and 11 months (Carbone et al., 1995). Low CD4+ count and involvement of bone and extranodal site indicate poor prognosis (Levine et al., 1991).

\section{Oral health-related quality of life among PLWHA}

The effects of HIV infection on the QOL of those who live with it are substantial and have been well documented. While the symptoms of HIV vary according to the stage of infection, studies have shown that health-related QOL (HRQOL) of PLWHA declines as the disease progresses and as the number of symptoms increase (Hays et al., 2000; Lorenz et al., 2006; Lorenz et al., 2001). In view of the fact that oral manifestations are among the most common symptoms of HIV which may provide strong indication of the disease progress (Bravo et al., 2006; Greenspan et al., 2000; Lewis et al., 2003 ; Patton, 2000; Pedreira et al., 2008), the presence of oral lesions can therefore have significant impact on the general well-being of individuals affected (Lorenz et al., 2001). 
Coulter et al. (2002) conducted a longitudinal study to determine the association between self-perceived oral health and general health in a sample of adults receiving medical care for HIV in the United States. Data was obtained via personal interviews that were conducted in three phases on a cohort that initially consisted of 2,864 patients. Oral health was assessed using seven items with a five-point scale on oral-related pain and discomfort, worry, appearance, and function, which were adapted from the General Oral Health Assessment Index (GOHAI) developed originally to measure oral health problems of older adults (Atchison \& Dolan, 1990), while the general health was assessed using 28 items on a 0 to 100 scale that measure physical functioning and emotional well-being of the patients. In both measures, higher score indicated better health. Results of the study suggested that oral health was strongly associated with physical and mental health of individuals with HIV. The authors concluded that oral health is indeed an essential component of general health and thus should be included in the assessment of HRQOL among PLWHA.

To date, available evidence on the association between oral symptoms and HRQOL among PLWHA is scarce. The impact of oral conditions in PLWHA was first reported by Coates et al. (1996) in a study among 54 HIV positive dental patients. The oral health status of patients with HIV, as measured by the Decayed, Missing, and Filled Teeth (DMFT) Index for measuring dental caries and the Community Periodontal Index of Treatment Needs (CPITN) for measuring periodontal disease, was compared with general dental patients receiving public-funded care in Adelaide, South Australia, while the impact on HRQOL was evaluated against another sample of Adelaide residents. The results showed that the CPITN scores were higher among the HIV group compared with the control group although dental caries experience did not differ significantly. More importantly, HIV patients have reported greater impact on HRQOL aspects due to disabling oral conditions than the comparison group. The impact of oral conditions was measured using the Oral Health Impact Profile (OHIP) questionnaire (Slade \& Spencer, 1994).

The OHIP questionnaire has been used to measure the impact of oral diseases on life experiences in various groups of patients and individuals. Originally developed in English, the OHIP questionnaire has been translated into other languages including Japanese, Korean, Malay, and Chinese (Bae et al., 2007; Ide et al., 2006; Saub et al., 2007; Wong et al., 2002). The questionnaire measures individual perceptions of impact, with questions divided into seven domains, namely functional limitation, physical pain, psychological discomfort, physical disability, psychological disability, social disability, and handicap. The original version contains 49 items (OHIP-49) as shown in Table 1.

The OHIP questionnaire has been the most commonly used instrument for assessing the oral health-related QOL (OHRQOL) among PLWHA. A five-point Likert scale response format is used to assess the frequency of impact caused by oral conditions during the previous 12 months, ranging from 'never' to 'very often'. From the results, the prevalence of impact can be determined which is the percentage of respondents reporting 1 or more impacts 'fairly often' or 'very often' (Slade et al., 2005). This information enables identification of those whose oral health impacts are chronic rather than transitory. A shorter version of the OHIP questionnaire with 14 items (OHIP-14) is also available to be used in settings where the use of 49 items is not suitable (Slade, 1997).

Yengopal \& Naidoo (2008) used the OHIP questionnaire to assess the impact of oral lesions in a convenient sample of 150 HIV infected adults seen at HIV clinics in Cape Town, South Africa. Two groups of HIV-positive patients were compared, a case group of 71 patients with HIV-associated oral manifestations, and a control group of 79 patients who had no 


\begin{tabular}{|c|c|}
\hline $\begin{array}{l}\text { Functional Limitation } \\
\text { - Had difficulty chewing any foods } \\
\text { - Trouble pronouncing words } \\
\text { - Noticed a tooth which doesn't look } \\
\text { right } \\
\text { - Felt that appearance has been affected } \\
\text { - Felt that breath has been stale } \\
\text { - Felt that sense of taste has worsened } \\
\text { - Had food catching in teeth or dentures } \\
\text { - Felt that digestion has worsened } \\
\text { - Felt that dentures have not been fitting } \\
\text { properly } \\
\text { Physical Pain } \\
\text { - Had painful aching in mouth } \\
\text { - Had a sore jaw } \\
\text { - Had headaches } \\
\text { - Had sensitive teeth with hot or cold } \\
\text { - Haod or drinks } \\
\text { - Had toothache } \\
\text { - Found it uncomfortable to eat any } \\
\text { - Hads } \\
\text { - Had uncomfortable spots in mouth } \\
\text { Psychological discomfort } \\
\text { - Been worried by dental problems } \\
\text { - Been self-conscious } \\
\text { - Been miserable } \\
\text { - Felt uncomfortable about appearance } \\
\text { - Felt tense }\end{array}$ & $\begin{array}{l}\text { Physical Disability } \\
\text { - Speech has been unclear } \\
\text { - People misunderstood some words } \\
\text { - Felt there has been less flavour in food } \\
\text { - Been unable to brush teeth properly } \\
\text { - Had to avoid eating some foods } \\
\text { - Had an unsatisfactory diet } \\
\text { - Been unable to eat with dentures } \\
\text { - Avoided smiling } \\
\text { - Had to interrupt meals } \\
\text { Psychological Disability } \\
\text { - Sleep has been interrupted } \\
\text { - Been upset } \\
\text { - Found it difficult to relax } \\
\text { - Felt depressed } \\
\text { - Concentration has been affected } \\
\text { - Been embarrassed } \\
\text { Social Disability } \\
\text { - Avoided going out } \\
\text { - Been less tolerant of spouse or partner } \\
\text { - Had trouble getting on with other } \\
\text { - people } \\
\text { - Heen a bit irritable with other people } \\
\text { Handicap } \\
\text { - Felt that general health has worsened } \\
\text { - Suffered any financial loss } \\
\text { - Been unable to enjoy other people's } \\
\text { - Fompany } \\
\text { - Batisfying in geen totally unable to function } \\
\text { - Been unable to work to full capacity }\end{array}$ \\
\hline
\end{tabular}

Table 1. Dimensions and items of the full version of the OHIP questionnaire (OHIP-49).

associated oral lesions. Results of the study revealed that oral candidiasis, angular cheilitis, and hairy leukoplakia were the most common oral lesions found among the cases, who also had significantly higher prevalence of other oral problems such as dental caries, periodontitis, dry mouth, and taste problems compared with patients in the control group. Data for assessment of impact obtained using the full version of the OHIP questionnaire was analysed by simple frequency count and by the use of item weights for each question. In general, the frequency count analysis showed that patients with HIV-associated oral lesions had higher impact scores in all oral health domains measured than those in the group without associated lesion. Further investigations using item weights showed that patients with associated oral lesions appeared to be more affected in terms of their functional limitation, physical pain, psychological discomfort, physical disability, and psychological 
disability compared with the other two dimensions, social disability and handicap. In total, the impact scores remain significantly different between the two groups with the case group reporting higher impact than the control group.

Similar results were found in a study by Mulligan et al. (2008) that compared a group of HIV-infected women $(n=597)$ with another group of at-risk HIV-negative women $(n=92)$. All the participants were part of the Women's Interagency HIV Study (WIHS) cohort that investigated manifestations of HIV in women at six sites throughout the United States (Chicago, Los Angeles, Bronx, Brooklyn, San Francisco and Washington). However, for the OHRQOL study, the participants were selected among women from only four WIHS sites (excluding Brooklyn and Washington). The shorter version of OHIP questionnaire was used in this study. The OHRQOL were determined at the beginning, during, and end of the study. Results showed that HIV-infected women had higher OHIP-14 scores, both at the baseline and during the study, than women at-risk. The difference between the two groups however was not significant at the last measurement. All things considered, the WIHS oral cohort study concluded that HIV-positive women had significantly poorer OHRQOL than HIV-negative women with an average of $10 \%$ difference in impact scores measured repeatedly over 5.5 years between the two groups. In addition, the HIV-positive group showed poorer oral health status than the control group as indicated by some dental caries and periodontal parameters measured clinically at the baseline.

Oral health status of HIV-infected patients was also found to be poor in a study among a sample of 101 HIV-positive adult patients, 32 women and 69 men, seen at the Immunodeficiency Unit of the Cascais Hospital Center, Portugal (Santo et al., 2010). Clinical examinations of dental caries status, periodontal health, oral hygiene, and dental prosthesis status were done. The mean DMFT for the whole sample was 16.4 (SD 8.42), which was higher than that found among general adult populations reported in other studies. The mean DMFT of general adults was 11.4 (SD 7.87) in Istanbul, Turkey (Namal et al., 2008), 12.5 (SD 7.1) in Oviedo, Spain (Alvarez-Arenal et al., 1996), and 12.8 in Australia (Do \& Roberts-Thomson, 2007). For the age group of 35-44 years old, the mean DMFT was higher in the HIV infected Portuguese patients which was 15.8 (SD 8.32) compared with that found in general population of similar age group. In Athens, Greece, the mean DMFT was 14.6 (SD 6.30) (Athanassouli et al., 1990), while in Pomerania, Germany, the mean DMFT was notably lower at 9.5 (SD 2.6) and 8.2 (SD 2.9) for female and male patients, respectively (Splieth et al., 2003). Further, examination of the periodontium showed that only $6.9 \%$ of the HIVpositive patients presented with healthy periodontium, while the majority of them $(77.2 \%)$ had periodontal pockets of at least $4-5 \mathrm{~mm}$ depth. Oral hygiene was also poor among the majority of patients $(63.4 \%)$ as determined by the Oral Hygiene Index that assessed the amount of plaque on six index teeth (Greene \& Vermillion, 1960). With regard to dental prosthesis status and perceived needs, while $28.8 \%$ of the patients were wearing dental prosthesis, $51.4 \%$ claimed that they needed dentures in the maxilla and $49.5 \%$ in the mandible. The OHRQOL among the HIV-positive Portuguese patients was assessed using the OHIP-14 questionnaire. Common oral health impact reported by the patients include discomfort when eating any foods $(58.4 \%)$, self-conscious because of teeth, mouth or dentures $(45.5 \%)$, painful aching in mouth $(38.6 \%)$, embarrassed because of oral problems $(38.6 \%)$, and felt tense because of problems with teeth, mouth or dentures $(34.7 \%)$.

Of 33.3 million PLWHA around the world in year 2009, 2.5 million were children under 15 years (UNAIDS, 2010), the prevalence and percentage of which has increased from 2.3 million of 40.3 million PLWHA in year 2005 (UNAIDS, 2005). Similar to adults, oral 
manifestations are common in children infected with HIV and have been found to be directly associated with the degree of immunosuppression and disease progression (Fonseca et al., 2000; Santos et al., 2001). In addition, oral candidiasis has also been the most commonly reported lesion in children, although the distributions of other oral lesions are somewhat different between children adults (Greenspan \& Greenspan, 2002; Patton et al., 2002; Ranganathan \& Hemalatha, 2006). While there is a need to update and revise the classification of HIV-associated oral lesions in the paediatric population (Coogan et al., 2005), the relevant documents seem to be inadequate. Studies on the oral health impact of children with HIV are also lacking although they suffer a higher prevalence of oral health problems like untreated dental caries than their peers (Flaitz et al., 2001; Massarente et al., 2009; Pongsiriwet et al., 2003).

A recent study on OHRQOL of 88 HIV-positive children in Brazil who had developed AIDS symptoms further highlighted the dismal picture (Massarente et al., 2011). Measurement of OHRQOL was done using the Brazilian Portuguese version of the Child Perceptions Questionnaire for children aged 11 to 14 years (CPQ 11-14) (Goursand et al., 2008). The CPQ11-14 is a 37-item measure of OHRQOL encompassing four domains: oral symptoms, functional limitations, emotional and social well-being (Jokovic et al., 2006). It is designed specifically for children in the particular age group, taking into account their cognitive abilities and lifestyles. Besides, there is another version of the questionnaire, CPQ 8-10, developed for an age range from 8 to 10 years (Jokovic et al., 2004). Results showed that higher viral load was associated with poorer OHRQOL where children with more severe AIDS manifestations ranked lower in all domains of OHRQOL measured.

\section{Summary}

Oral manifestations are common in PLWHA. Oral lesions, that may be seen as early clinical features of HIV infection, has been used to evaluate the immunological status of HIVinfected patients as measured by reduced CD4 $+\mathrm{T}$ cell count and increased HIV RNA quantity in plasma. Besides being important indicators of HIV infection, oral lesions may predict progression of the disease to AIDS. Therefore it is imperative that health care providers, particularly oral health professionals, are able to identify the signs and symptoms of HIV-related oral lesions and recognize the significant role of these lesions in diagnosis and management of HIV infection.

Introduction of HAART has resulted in considerable reduction in prevalence of oral lesions in HIV-infected individuals. However, as the HAART regimens may not be available or accessible to those in need, oral lesions thus remain as indispensable component of HIV infection. While there is continuing interest to investigate oral manifestations and immunologic responses among PLWHA, the study on OHRQOL has emerged as an important focus in HIV research. The social impact of HIV-related oral lesions and other oral health problems is recognised as an important attribute used to assess the outcomes of oral health services, to assist in cost-benefit analysis, and to monitor individual patient care. Although to date, studies on the OHRQOL among HIV-infected individuals are not many, the current available evidence suggested that the impact is substantial. Collectively, this chapter highlights the important role of dentists in the interdisciplinary management of PLWHA. 


\section{References}

Alvarez-Arenal A., Alvarez-Riesgo J., Pena Lopez J., Fernandez Vazquez J. \& Villa Vigil M. (1996). DMFT and treatment needs in adult population of Oviedo, Spain. Community Dent Oral Epidemiol 24: 17-20

Anil S. \& Challacombe S. (1997). Oral lesions of HIV and AIDS in Asia: an overview. Oral Dis 3 Suppl 1: S36-40

Atchison K. \& Dolan T. (1990). Development of the Geriatric Oral Health Assessment Index. J Dent Educ 54: 680-7

Athanassouli T., Koletsi-Kounari H., Mamai-Homata H. \& Panagopoulos H. (1990). Oral health status of adult population in Athens, Greece. Community Dent Oral Epidemiol 18: $82-4$

Bae K., Kim H., Jung S., Park D., Kim J., Paik D. \& Chung S. (2007). Validation of the Korean version of the oral health impact profile among the Korean elderly. Community Dent Oral Epidemiol 35: 73-9

Bhayat A., Yengopal V. \& Rudolph M. (2010). Predictive value of group I oral lesions for HIV infection. Oral Surg Oral Med Oral Pathol Oral Radiol Endod 109: 720-3

Boshoff C., Schulz T., Kennedy M., Graham A., Fisher C., Thomas A., McGee J., Weiss R. \& O'Leary J. (1995). Kaposi's sarcoma-associated herpesvirus infects endothelial and spindle cells. Nat Med 1: 1274-8

Bravo I., Correnti M., Escalona L., Perrone M., Brito A., Tovar V. \& Rivera H. (2006). Prevalence of oral lesions in HIV patients related to CD4 cell count and viral load in a Venezuelan population. Med Oral Patol Oral Cir Bucal 11: E33-9

Buchacz K., Baker R., Palella Jr F., Chmiel J., Lichtenstein K., Novak R., Wood K., Brooks J. \& HOPS Investigators (2010). AIDS-defining opportunistic illnesses in US patients, 1994-2007: a cohort study. AIDS Care 24: 1549-59

Campo J., Del Romero J., Castilla J., García S., Rodríguez C. \& Bascones A. (2002). Oral candidiasis as a clinical marker related to viral load, CD4 lymphocyte count and CD4 lymphocyte percentage in HIV-infected patients. J Oral Pathol Med 31: 5-10

Carbone A., Vaccher E., Barzan L., Gloghini A., Volpe R., De Re V., Boiocchi M., Monfardini S. \& Tirelli U. (1995). Head and neck lymphomas associated with human immunodeficiency virus infection. Arch Otolaryngol Head Neck Surg 121: 210-8

Carr R. \& Gramling L. (2004). Stigma: a health barrier for women with HIV/AIDS. J Assoc Nurses AIDS Care 15: 30-9

Casiglia J. \& Woo S. (2000). Oral manifestations of HIV infection. Clin Dermatol 18: 541-51

Chattopadhyay A., Caplan D., Slade G., Shugars D., Tien H. \& Patton L. (2005). Risk indicators for oral candidiasis and oral hairy leukoplakia in HIV-infected adults. Community Dent Oral Epidemiol 33: 35-44

Coates E., Slade G., Goss A. \& Gorkic E. (1996). Oral conditions and their social impact among HIV dental patients. Aust Dent J 41: 33-6

Coogan M., Greenspan J. \& Challacombe S. (2005). Oral lesions in infection with human immunodeficiency virus. Bull World Health Organ 83: 700-6

Coulter I., Heslin K., Marcus M., Hays R., Freed J., Der-Martirosia C., Guzmán-Becerra N., Cunningham W., Andersen R. \& Shapiro M. (2002). Associations of self-reported 
oral health with physical and mental health in a nationally representative sample of HIV persons receiving medical care. Qual Life Res 11: 57-70

Cruchley A., Williams D., Niedobitek G. \& Young L. (1997). Epstein-Barr virus: biology and disease. Oral Dis 3 Suppl 1: S156-63

Do L. \& Roberts-Thomson K. (2007). Dental caries experience in the Australian adult population. Aust Dent J 52: 249-51

Dobalian A., Andersen R., Stein J., Hays R., Cunningham W. \& Marcus M. (2003). The impact of HIV on oral health and subsequent use of dental services. J Public Health Dent 63: 78-85

EC-Clearinghouse \& WHO (1993). EC-Clearinghouse on Oral Problems Related to HIV Infection and WHO Collaborating Centre on Oral Manifestations of the Immunodeficiency Virus. Classification and diagnostic criteria for oral lesions in HIV infection. J Oral Pathol Med 22: 289-91

Eyeson J., Tenant-Flowers M., Cooper D., Johnson N. \& Warnakulasuriya K. (2002). Oral manifestations of an HIV positive cohort in the era of highly active anti-retroviral therapy (HAART) in South London. J Oral Pathol Med 31: 169-74

Ferreira S., Noce C., Júnior A., Gonçalves L., Torres S., Meeks V., Luiz R. \& Dias E. (2007). Prevalence of oral manifestations of HIV infection in Rio De Janeiro, Brazil from 1988 to 2004. AIDS Patient Care STDS 21: 724-31

Fisher S. \& Fisher R. (2004). The epidemiology of non-Hodgkin's lymphoma. Oncogene 23: 6524-34

Flaitz C., Wullbrandt B., Sexton J., Bourdon T. \& Hicks J. (2001). Prevalence of orodental findings in HIV-infected Romanian children. Pediatr Dent 23: 44-50

Fonseca R., Cardoso A. \& Pomarico I. (2000). Frequency of oral manifestations in children infected with human immunodeficiency virus. Quintessence Int 31: 419-22

Franceschi S., Maso L., Rickenbach M., Polesel J., Hirschel B., Cavassini M., Bordoni A., Elzi L., Ess S., Jundt G., Mueller N. \& Clifford G. (2008). Kaposi sarcoma incidence in the Swiss HIV Cohort Study before and after highly active antiretroviral therapy. Br J Cancer 99: 800-4

Gascón P. \& Schwartz R. (2000). Kaposi's sarcoma. New treatment modalities. Dermatol Clin 18: $169-75$

Gillespie G. \& Mariño R. (1993). Oral manifestations of HIV infection: a Panamerican perspective. J Oral Pathol Med 22: 2-7

Glick M., Muzyka B., Lurie D. \& Salkin L. (1994). Oral manifestations associated with HIVrelated disease as markers for immune suppression and AIDS. Oral Surg Oral Med Oral Pathol Oral Radiol Endod 77: 344-9

Goursand D., Paiva S., Zarzar P., Ramos-Jorge M., Cornacchia G., Pordeus I. \& Allison P. (2008). Cross-cultural adaptation of the Child Perceptions Questionnaire 1114 (CPQ11-14) for the Brazilian Portuguese language. Health Qual Life Outcomes 6

Green T. \& Eversole L. (1989). Oral lymphomas in HIV-infected patients: association with Epstein-Barr virus DNA. Oral Surg Oral Med Oral Pathol 67: 437-42

Greene J. \& Vermillion J. (1960). The oral hygiene index: a method for classifying oral hygiene status. JADA 61: 29-35 
Greenspan D. \& Greenspan J. (1992). Significance of oral hairy leukoplakia. Oral Surg Oral Med Oral Pathol Oral Radiol Endod 73: 151-4

Greenspan D., Komaroff E., Redford M., Phelan J., Navazesh M., Alves M., Kamrath H., Mulligan R., Barr C. \& Greenspan J. (2000). Oral mucosal lesions and HIV viral load in the Women's Interagency HIV Study (WIHS). J Acquir Immune Defic Syndr 25: 4450

Greenspan J. \& Greenspan D. (2002). The epidemiology of the oral lesions of HIV infection in the developed world. Oral Dis 8 Suppl 2: 34-9

Grossman H.A., Sullivan P.S. \& Wu A.W. (2003). Quality of life and HIV: Current assessment tools and future directions for clinical practice. The AIDS Reader 12: 58397

Hays R., Cunningham W., Sherbourne C., Wilson I., Wu A., Cleary P., McCaffrey D., Fleishman J., Crystal S., Collins R., Eggan F., Shapiro M. \& Bozzette S. (2000). Health-related quality of life in patients with human immunodeficiency virus infection in the United States: results from the HIV Cost and Services Utilization Study. Am J Med 108: 714-22

Ide R., Yamamoto R. \& Mizoue T. (2006). The Japanese version of the Oral Health Impact Profile (OHIP)--validation among young and middle-aged adults. Community Dent Health 23: 158-63

Ironson G., O'Cleirigh C., Fletcher M., Laurenceau J., Balbin E., Klimas N., Schneiderman N. \& Solomon G. (2005). Psychosocial factors predict CD4 and viral load change in men and women with human immunodeficiency virus in the era of highly active antiretroviral treatment. Psychosom Med 67: 1013-21

Jokovic A., Locker D. \& Guyatt G. (2006). Short forms of the Child Perceptions Questionnaire for 11-14-year-old children (CPQ11-14): development and initial evaluation. Health Qual Life Outcomes 4

Jokovic A., Locker D., Tompson B. \& Guyatt G. (2004). Questionnaire for measuring oral health-related quality of life in eight- to ten-year-old children. Pediatr Dent 26: $512-8$

Kaplan J., Hanson D., Dworkin M., Frederick T., Bertolli J., Lindegren M., Holmberg S. \& Jones J. (2000). Epidemiology of human immunodeficiency virus-associated opportunistic infections in the United States in the era of highly active antiretroviral therapy. Clin Infect Dis 30 Suppl 1: S5-14

Kaplan L., Kahn J., Crowe S., Northfelt D., Neville P., Grossberg H., Abrams D., Tracey J., Mills J. \& Volberding P. (1991). Clinical and virologic effects of recombinant human granulocyte-macrophage colony-stimulating factor in patients receiving chemotherapy for human immunodeficiency virus-associated non-Hodgkin's lymphoma: results of a randomized trial. J Clin Oncol 9: 929-40

Krentz H., Kliewer G. \& Gill M. (2005). Changing mortality rates and causes of death for HIV-infected individuals living in Southern Alberta, Canada from 1984 to 2003. HIV Med 6: 99-106

Lamster I., Begg M., Mitchell-Lewis D., Fine J., Grbic J., Todak G., el-Sadr W., Gorman J., Zambon J. \& Phelan J. (1994). Oral manifestations of HIV infection in homosexual men and intravenous drug users. Study design and relationship of epidemiologic, 
clinical, and immunologic parameters to oral lesions. Oral Surg Oral Med Oral Pathol 78: $163-74$

Laskaris G. (1996). Oral manifestations of infectious diseases. Dent Clin North Am 40: 395423

Laskaris G. (2000). Oral manifestations of HIV disease. Clin Dermatol 18: 447-55

Leserman J. (2003). HIV disease progression: depression, stress, and possible mechanisms. Biol Psychiatry 54: 295-306

Leserman J. (2008). Role of depression, stress, and trauma in HIV disease progression. Psychosom Med 70: 539-45

Levine A., Sullivan-Halley J., Pike M., Rarick M., Loureiro C., Bernstein-Singer M., Willson E., Brynes R., Parker J. \& Rasheed S. (1991). Human immunodeficiency virus-related lymphoma. Prognostic factors predictive of survival. Cancer 68: 2466-72

Lewis D., Callaghan M., Phiri K., Chipwete J., Kublin J., Borgstein E. \& Zijlstra E. (2003 ). Prevalence and indicators of HIV and AIDS among adults admitted to medical and surgical wards in Blantyre, Malawi. Trans $R$ Soc Trop Med Hyg 97: 91-6

Little J., Melnick S., Rhame F., Balfour Jr H., Decher L., Rhodus N., Merry J., Walker P., Miller C. \& Volberding P. (1994). Prevalence of oral lesions in symptomatic and asymptomatic HIV patients. Gen Dent 42: 446-50

Lorenz K., Cunningham W., Spritzer K. \& Hays R. (2006). Changes in symptoms and healthrelated quality of life in a nationally representative sample of adults in treatment for HIV. Qual Life Res 15: 951-8

Lorenz K., Shapiro M., Asch S., Bozzette S. \& Hays R. (2001). Associations of symptoms and health-related quality of life: findings from a national study of persons with HIV infection. Ann Intern Med 134: 854-60

Mascarenhas A.K. \& Smith S.R. (1999). Factors associated with utilization of care for oral lesions in HIV disease. Oral Surg Oral Med Oral Pathol Oral Radiol Endod 87: 708-13

Massarente D., Domaneschi C. \& Antunes J. (2009). Untreated dental caries in a Brazilian paediatric AIDS patient population. Oral Health Prev Dent 7: 403-10

Massarente D., Domaneschi C., Marques H., Andrade S., Goursand D. \& Antunes J. (2011). Oral health-related quality of life of paediatric patients with AIDS. BMC Oral Health 11: 2

Melnick S., Hannan P., Decher L., Little J., Rhame F., Balfour Jr H. \& Volberding P. (1991). Increasing CD8+ $\mathrm{T}$ lymphocytes predict subsequent development of intraoral lesions among individuals in the early stages of infection by the human immunodeficiency virus. J Acquir Immune Defic Syndr 4: 1199-207

Mocroft A., Kirk O., Clumeck N., Gargalianos-Kakolyris P., Trocha H., Chentsova N., Antunes F., Stellbrink H., Phillips A. \& Lundgren J. (2004). The changing pattern of Kaposi sarcoma in patients with HIV, 1994-2003: the EuroSIDA Study. Cancer 100: 2644-54

Mocroft A., Vella S., Benfield T., Chiesi A., Miller V., Gargalianos P., d'Arminio Monforte A., Yust I., Bruun J., Phillips A. \& Lundgren J. (1998). Changing patterns of mortality 
across Europe in patients infected with HIV-1. EuroSIDA Study Group. Lancet 352: 1725-30

Mulligan R., Seirawan H., Alves M., Navazesh M., Phelan J., Greenspan D., Greenspan J. \& Mack W. (2008). Oral health-related quality of life among HIV-infected and at-risk women. Community Dent Oral Epidemiol 36: 549-57

Namal N., Can G., Vehid S., Koksal S. \& Kaypmaz A. (2008). Dental health status and risk factors for dental caries in adults in Istanbul, Turkey. East Mediterr Health J 14: $110-8$

Nicolatou-Galitis O., Velegraki A., Paikos S., Economopoulou P., Stefaniotis T., Papanikolaou I. \& Kordossis T. (2004). Effect of PI-HAART on the prevalence of oral lesions in HIV-1 infected patients. A Greek study. Oral Dis 10: 145-50

Nittayananta W., Chanowanna N., Sripatanakul S. \& Winn T. (2001). Risk factors associated with oral lesions in HIV-infected heterosexual people and intravenous drug users in Thailand. J Oral Pathol Med 30: 224-30

Nittayananta W., Chanowanna N., Winn T., Silpapojakul K., Rodklai A., Jaruratanasirikul S. \& Liewchanpatana K. (2002). Co-existence between oral lesions and opportunistic systemic diseases among HIV-infected subjects in Thailand. J Oral Pathol Med 31: $163-8$

Nittayananta W. \& Chungpanich S. (1997). Oral lesions in a group of Thai people with AIDS. Oral Dis 3 Suppl 1

Noce C., Ferreira S., Silva Júnior A. \& Dias E. (2009). Association between socioeconomic status and HIV-associated oral lesions in Rio de Janeiro from 1997 to 2004. Braz Oral Res 23: 149-54

Patton L. (2000). Sensitivity, specificity, and positive predictive value of oral opportunistic infections in adults with HIV/AIDS as markers of immune suppression and viral burden. Oral Surg Oral Med Oral Pathol Oral Radiol Endod 90: 182-8

Patton L. (2003). HIV disease. Dent Clin North Am 47: 467-92

Patton L., McKaig R., Strauss R., Rogers D. \& Eron J.J. (2000). Changing prevalence of oral manifestations of human immuno-deficiency virus in the era of protease inhibitor therapy. Oral Surg Oral Med Oral Pathol Oral Radiol Endod 89: 299-304

Patton L., Phelan J., Ramos-Gomez F., Nittayananta W., Shiboski C. \& Mbuguye T. (2002). Prevalence and classification of HIV-associated oral lesions. Oral Dis 8 Suppl 2: 98109

Patton L., Strauss R., McKaig R., Porter D. \& Eron J.J. (2003). Perceived oral health status, unmet needs, and barriers to dental care among HIV/AIDS patients in a North Carolina cohort: impacts of race. J Public Health Dent 63: 86-91

Pedreira E., Cardoso C., Barroso Edo C., Santos J., Fonseca F. \& Taveira L. (2008). Epidemiological and oral manifestations of HIV-positive patients in a specialized service in Brazil. J Appl Oral Sci 16: 369-75

Piedbois P., Frikha H., Martin L., Levy E., Haddad E. \& Le Bourgeois J. (1994). Radiotherapy in the management of epidemic Kaposi's sarcoma. Int J Radiat Oncol Biol Phys 30: 1207-11 
Pongsiriwet S., Iamaroon A., Kanjanavanit S., Pattanaporn K. \& Krisanaprakornkit S. (2003). Oral lesions and dental caries status in perinatally HIV-infected children in Northern Thailand. Int J Paediatr Dent 13: 180-5

Ramírez-Amador V., Anaya-Saavedra G., Calva J., Clemades-Pérez-de-Corcho T., LópezMartínez C., González-Ramírez I. \& Sierra-Madero J. (2006). HIV-related oral lesions, demographic factors, clinical staging and anti-retroviral use. Arch Med Res 37: 646-54

Ramírez-Amador V., Esquivel-Pedraza L., Sierra-Madero J., Anaya-Saavedra G., González-Ramírez I. \& Ponce-de-León S. (2003). The Changing Clinical Spectrum of Human Immunodeficiency Virus (HIV)-Related Oral Lesions in 1,000 Consecutive Patients: A 12-Year Study in a Referral Center in Mexico. Medicine (Baltimore) 82: 39-50

Ranganathan K. \& Hemalatha R. (2006). Oral lesions in HIV infection in developing countries: an overview. Adv Dent Res 19: 63-8

Roberts M., Brahim J. \& Rinne N. (1988). Oral manifestations of AIDS: a study of 84 patients. J Am Dent Assoc 116: 863-6

Robinson P. (1997). Treatment of HIV-associated periodontal diseases. Oral Dis 3 Suppl 1: S238-40

Santo A., Tagliaferro E., Ambrosano G., Meneghim M. \& Pereira A. (2010). Dental status of Portuguese HIV+ patients and related variables: a multivariate analysis. Oral Dis 16: $176-84$

Santos L., Castro G., de Souza I. \& Oliveira R. (2001). Oral manifestations related to immunosuppression degree in HIV-positive children. Braz Dent J 12: 135-8

Saub R., Locker D., Allison P. \& Disman M. (2007). Cross-cultural adaptation of the Oral Health Impact Profile (OHIP) for the Malaysian adult population. Community Dent Health 24: 166-75

Scully C. \& McCarthy G. (1992). Management of oral health in persons with HIV infection. Oral Surg Oral Med Oral Pathol Oral Radiol Endod 73: 215-25

Shiboski C. (2002). HIV-related oral disease epidemiology among women: year 2000 update. Oral Dis 8 Suppl 2: 44-8 ISSN 1354-523X

Shiboski C., Neuhaus J., Greenspan D. \& Greenspan J. (1999a). Effect of receptive oral sex and smoking on the incidence of hairy leukoplakia in HIV-positive gay men. $J$ Acquir Immune Defic Syndr 21: 236-42

Shiboski C., Wilson C., Greenspan D., Hilton J., Greenspan J., Moscicki A. \& Adolescent Medicine HIV/AIDS Research Network (2001). HIV-related oral manifestations among adolescents in a multicenter cohort study. J Adolesc Health 29: 109-14

Shiboski C.H., Palacio H., Neuhaus J.M. \& Greenblatt R.M. (1999b). Dental care access and use among HIV-infected women. Am J Public Health 89: 834-9

Silverman Jr S., Migliorati C., Lozada-Nur F., Greenspan D. \& Conant M. (1986). Oral findings in people with or at high risk for AIDS: a study of 375 homosexual males. J Am Dent Assoc 112: 187-92

Slade G. (1997). Derivation and validation of a short-form oral health impact profile. Community Dent Oral Epidemiol 25: 284-90 
Slade G., Nuttall N., Sanders A., Steele J., Allen P. \& Lahti S. (2005). Impacts of oral disorders in the United Kingdom and Australia. Br Dent J 198: 489-93

Slade G. \& Spencer A. (1994). Development and evaluation of the Oral Health Impact Profile. Community Dent Health 11: 3-11

Splieth C., Schwahn C., Bernhardt O., Kocher T., Born G., John U. \& Hensel E. (2003). Caries prevalence in an adult population: results of the Study of Health in Pomerania, Germany (SHIP). Oral Health Prev Dent 1: 149-55

Tappuni A. \& Fleming G. (2001). The effect of antiretroviral therapy on the prevalence of oral manifestations in HIV-infected patients: a UK study. Oral Surg Oral Med Oral Pathol Oral Radiol Endod 92: 623-8

Tüzün Y., Kalayciyan A., Engin B. \& Tüzün B. (2005). Life-threatening disorders of mucous membranes. Clin Dermatol 23: 267-75

Tukutuku K., Muyembe-Tamfum L., Kayembe K., Odio W., Kandi K. \& Ntumba M. (1990). Oral manifestations of AIDS in a heterosexual population in a Zaire hospital. J Oral Pathol Med 19: 232-4

UNAIDS (2005). AIDS epidemic update UNAIDS/WHO: Geneva.

UNAIDS (2010). Global Report: UNAIDS Report on the Global AIDS Epidemic. UNAIDS: Geneva.

Wang J., Stebbing J. \& Bower M. (2007). HIV-associated Kaposi sarcoma and gender. Gend Med 4: 266-73

Wanzala P., Manji F., Pindborg J. \& Plummer F. (1989). Low prevalence of oral mucosal lesions in HIV-1 seropositive African women. J Oral Pathol Med 18: 416-8

Webster-Cyriaque J., Edwards R., Quinlivan E., Patton L., Wohl D. \& Raab-Traub N. (1997). Epstein-Barr virus and human herpesvirus 8 prevalence in human immunodeficiency virus-associated oral mucosal lesions. J Infect Dis 175: 132432

Whitby D., Howard M., Tenant-Flowers M., Brink N., Copas A., Boshoff C., Hatzioannou T., Suggett F., Aldam D. \& Denton A. (1995). Detection of Kaposi sarcoma associated herpesvirus in peripheral blood of HIV-infected individuals and progression to Kaposi's sarcoma. Lancet 346: 799-802

WHO (2008). HIV/AIDS and mental health. Report by the Secretariat. World Health Organization: Geneva.

WHO, UNICEF \& UNAIDS (2009). Towards universal access: scaling up priority HIV/AIDS interventions in the health sector. Progress report 2009. World Health Organization: Geneva.

Wong M., Lo E. \& McMillan A. (2002). Validation of a Chinese version of the Oral Health Impact Profile (OHIP). Community Dent Oral Epidemiol 30: 423-30

Wood C. \& Harrington Jr W. (2005). AIDS and associated malignancies. Cell Res 15: 94752

Yang C., Chen M., Hsieh S., Sheng W., Sun H., Hung C. \& Chang S. (2010). Non-Hodgkin's lymphoma in patients with human immunodeficiency virus infection in Taiwan. $J$ Microbiol Immunol Infect 43: 278-84 
Yang C., Huang Y., Hsiao C., Yeh Y., Liou H., Hung C. \& Yang S. (2008). Trends of mortality and causes of death among HIV-infected patients in Taiwan, 1984-2005. HIV Med 9: $535-43$

Yengopal V. \& Naidoo S. (2008). Do oral lesions associated with HIV affect quality of life? Oral Surg Oral Med Oral Pathol Oral Radiol Endod 106: 66-73 


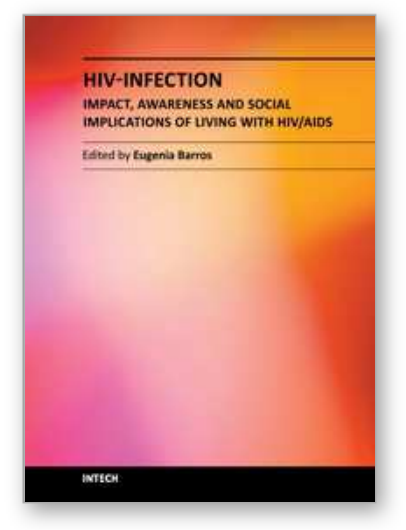

\author{
HIV-infection - Impact, Awareness and Social Implications of living \\ with HIV/AIDS \\ Edited by Dr. Eugenia Barros
}

ISBN 978-953-307-343-9

Hard cover, 336 pages

Publisher InTech

Published online 26, October, 2011

Published in print edition October, 2011

The past few decades have seen the escalation of HIV-infections and the 'frantic' search for new drugs to treat the millions of people that live with HIV-AIDS. However because HIV-AIDS cannot be cured, but only controlled with drugs, and the Antiretroviral (ARV) treatment itself results in some undesirable conditions, it is important to generate wider awareness of the plight of people living with this condition. This book attempts to provide information of the initiatives that have been used, successfully or unsuccessfully, to both prevent and combat this 'pandemic' taking into consideration the social, economic, cultural and educational aspects that involve individuals, communities and the countries affected.

\title{
How to reference
}

In order to correctly reference this scholarly work, feel free to copy and paste the following:

Norkhafizah Saddki and Wan Majdiah Wan Mohamad (2011). Oral Health-Related Quality of Life Among People Living with HIV/AIDS, HIV-infection - Impact, Awareness and Social Implications of living with HIV/AIDS, Dr. Eugenia Barros (Ed.), ISBN: 978-953-307-343-9, InTech, Available from:

http://www.intechopen.com/books/hiv-infection-impact-awareness-and-social-implications-of-living-with-hivaids/oral-health-related-quality-of-life-among-people-living-with-hiv-aids

\section{INTECH}

open science | open minds

\author{
InTech Europe \\ University Campus STeP Ri \\ Slavka Krautzeka 83/A \\ 51000 Rijeka, Croatia \\ Phone: +385 (51) 770447 \\ Fax: +385 (51) 686166 \\ www.intechopen.com
}

\author{
InTech China \\ Unit 405, Office Block, Hotel Equatorial Shanghai \\ No.65, Yan An Road (West), Shanghai, 200040, China \\ 中国上海市延安西路65号上海国际贵都大饭店办公楼 405 单元 \\ Phone: +86-21-62489820 \\ Fax: +86-21-62489821
}


(C) 2011 The Author(s). Licensee IntechOpen. This is an open access article distributed under the terms of the Creative Commons Attribution 3.0 License, which permits unrestricted use, distribution, and reproduction in any medium, provided the original work is properly cited. 